\title{
Trace Element Bioaccumulation Potentials of Pleurotus ostreatus: Its Implication in Nutrition-Based Therapy.
}

\author{
Aaron, H. A. ${ }^{1}$, Markson, A. A. ${ }^{2}$, Bassey, G. A. ${ }^{2}$, Agba, M. O. ${ }^{2}$ \\ and Akpan, J. B. \\ ${ }^{l}$ Department of Home Ecocnomics, College of Education, Akamkpa, Cross River State. Nigeria. \\ ${ }^{2}$ Department of Botany, University of Calabar, Calabar, Cross River State, Nigeria
}

\begin{abstract}
This study was carried out to assess the capacity of Pleurotus ostreatus to bio-accumulate trace elements from petroleum product-amended growth substrates. The test mushroom was grown on two (2) substrates namely, banana leaves $(B L)$ and sawdust $(S D)$ substrates which were amended with $(5 \mathrm{ml}, 10 \mathrm{ml}$ and $15 \mathrm{ml}$ ) of crude oil, diesel and spent engine oil separately. The fruit-bodies harvested from the substrates were subjected to analysis for trace elements. The ten elements of interest were cadmium, copper, chromium, cobalt, manganese, zinc, iron, lead, mercury and nickel. All the elements analyzed for were found in reasonable levels in the mushroom except for mercury $(\mathrm{Hg})$ which was below detectable levels $(B D L)$. The highest amounts of elements were detected in mushrooms from crude oil-based substrates with zinc at the top of the list with 51.19 $\mathrm{mg} / 100 \mathrm{~g}$, Iron $(32.40 \mathrm{mg} / \mathrm{lo0g})$ and manganese $(28.36 \mathrm{mg} / 100 \mathrm{~g})$ were next. Less than one milligram (1mg) of copper was bio-accumulated per $100 \mathrm{~g}$ of the edible portion. In spent oil-and diesel-amended substrates, zinc was still the highest bio-accumulated with values of $33.00 \mathrm{mg} / 100 \mathrm{~g}$ and $27.22 \mathrm{mg} / 100 \mathrm{~g}$ respectively. About $18.9 \mathrm{mg} / 100 \mathrm{~g}$ and $13.92 \mathrm{mg} / 100 \mathrm{~g}$ of manganese were extracted and retained the mushroom fruit-body harvested from diesel and spent oil-rich substrates respectively. The amount of iron found in the test mushroom was, however, lower $(14.93 \mathrm{mg} / 100 \mathrm{~g})$ in fruit-bodies harvested from spent oil when compared with those $(21.20 \mathrm{mg} / 100 \mathrm{~g})$ from diesel - amended substrates while copper bio-accumulated more in fruit-bodies obtained from spent oil than those from diesel-rich substrates. The levels of these important trace elements reported in some commonly consumed plants and animal products are low. The use of mushrooms to extract useful trace elements from amended growth substrates is here presented as an alternative to inorganic food supplements for the treatment of nutrition-related illnesses.
\end{abstract}

Keywords:Trace elements, bio-accumulation, Pleurotusostreatus, nutrition-based therapy

\section{Introduction}

Fungi are nucleated, usually filamentous, spore-bearing organisms devoid of chlorophyll; typically reproducing both sexually and asexually; living as parasites in plants, animals, or other fungi, or as saprophytes on plants or animal remains, in aquatic, marine, terrestrial, or sub-aerial habitats. The basic structural unit of fungi is the hypha. A network of hyphae becomes the mycelium. The fungus ramifies its growth substrates with the mycelium secreting hydrolytic enzymes which degrade substances (plant materials, animal remains, waste products of any kind) in the substrate and bio-accumulate them in soluble forms as nutrients.Sporophores commonly referred to as mushrooms are fruit-bodies of fungi. They are pseudo-parenchymatous fungal tissues formed through the compaction of fungal mycelia[1]. Mushroom is made up of the mycelia, stipe and the pileus. Any substances absorbed through the mycelia accumulate in the fruit-body (mushroom) of the fungus.

The inherent capacity of some fungi to biodegrade and bio-accumulate substances in their growth substrates have been exploited to clean up and decontaminate polluted environments [2,3,4,5]. Pleurotus ostreatus and Pleurotus pulmonarius, both edible mushrooms have been reported to degrade crude oil utilizing the carbon skeleton for metabolic activities and growth [6]. Lentinus subnudus, a white rot fungus, has been credited with the ability to mineralize soils contaminated with crude oil [2]. It has been demonstrated that biodegradation of petroleum products by $P$. ostreatus yielded useful trace elements which they bio-accumulate when it was cultured on petroleum product-rich substrates [7]. Among the accumulated heavy metals reported were copper, Manganese, iron, cobalt and Zinc, with Zinc found in highest $(51.19 \mathrm{mg} / \mathrm{kg})$ amounts. All the elements recorded were found to be at WHO permissible levels for consumption.

Trace elements are chemical elements required in minute quantities by an organism to maintain proper physical functioning $[8,9]$. Essential trace elements needed by the human body for proper functioning include iron $(\mathrm{Fe})$, cobalt $(\mathrm{Co})$, manganese $(\mathrm{Mn})$, copper $(\mathrm{Cu})$ and zinc $(\mathrm{Zn})$, chromium $(\mathrm{Cr})$, fluorine $(\mathrm{Fl})$, iodine $\left(\mathrm{I}_{2}\right)$, selenium (Se), molybdenum (Mo) and vanadium ( $\mathrm{Vn}$ ). The need to meet the Required Dietary Allowance (RDA) of these elements is important in guaranteeing good health and vitality and is critical for the survival of humans in certain circumstance. For instance, iron is necessary for red blood cell formation and required for 
transport of oxygen throughout the body. It is also important for brain function. Higher amounts (double) is needed in women of childbearing age since high volume of blood is necessary during pregnancy to carter for the increased need by the fetus as well as to make for the increased blood losses during delivery [9]. Chromium aids in glucose metabolism and helps regulate blood sugar by potentiating insulin and serving as a component of glucose tolerance factor $[10,11]$.

Cobalt is known to promote the formulation of red blood cells and it serves as a component of vitamin B-12(cobalamine) [12]. Copper is essential to normal red blood cell formation and connective tissue formation. It acts as a catalyst to store and release iron to help form hemoglobin and contributes to central nervous system function. Zinc is an essential part of more than 300 enzymes involved in digestion, metabolism, and reproduction and wound healing. It plays a critical role in immune response and influences hormones.It is vital for activating growth and physical and neurological development in infants, children and teenagers. Zinc is vital in protecting the body from illnesses and fighting infections. It can reduce the duration and severity of a common cold and halt diarrhea. Consumption of raised levels of zinc removes excess copper from the body [11].

Reports have it that in the recent analyses of data obtained for nutrient and supplement intake in the United States conducted by the U.S. National Institutes of Health and other government agencies indicate that the vast majority of people in both affluent and emerging industrialized countries do not reach even 75 percent of the RDAs for numerous trace minerals. It has been documented that about two billion people worldwide do not receive enough zinc through their diet. Zinc deficiency is a major health problem in developing countries. Young children are most affected. Zinc deficiency weakens their immune system and predisposes them to infectious diseases such as diarrhea, pneumonia and malaria which claim millions of lives of children under the age of five every year [9]. UNICEF estimates that diarrhea accounts for nearly 2 million deaths among children under the age of five every year [13]. The children become dehydrated, losing all body fluids and nutrients. Diarrhea is a preventable and treatable disease, but in developing countries, only $35 \%$ of children with diarrhea receive the recommended treatment consisting of oral rehydration salts and zinc supplements. Zinc deficiency is also accountable for physical and intellectual retardation and stunting, preventing children from developing to their full potential $[8,9]$. Iron deficiency is associated with decreased supply of oxygen to tissues and organs resulting in symptoms like body weakness, slow cognitive and social development in children, decreased immune function, breathlessness, insomnia, headaches, loss of appetite and pallor[11]. Findings suggest that deficiency in copper is one prominent factor increasing the risk of developing coronary heart disease. Diets deficient in cobalt may lead to numbness, fatigue and tingling in the hand and feet. Over time, the condition also leads to decreased nerve function [11].

The World Health Organization (WHO) [14] considers iron deficiency the number one nutritional disorder in the world. As many as $80 \%$ of the world's population may be iron deficient, while $30 \%$ may have iron deficiency anemia. Iron deficiency is the most prevalent nutritional problem globally. It has been reported that $2 / 3$ of children and women of child-bearing age in developing countries suffer from iron deficiency, $1 / 3$ suffering from severe deficiency and anemia. In developed countries, between $10-20 \%$ of child-bearing age women are said to be anemic. Iron is the least plentiful nutrient in the typical British diet and anemia is fairly common in the UK $[10,14,15]$.

Dietary sources of trace elements are varied. They are obtained from plant, animal and inorganic sources. Some are taken as food supplements, especially, when clinical symptoms of deficiency are experienced. However, the cost of food supplements is high and not affordable by the poor locals. The major sources of zinc are (red) meat, poultry, fish and seafood, whole cereals and dairy products. Zinc is most available to the body from meat. Red meat is notorious for its raised cholesterol levels and the associated coronary heart disorders. The bioavailability of zinc in plant-based foods is generally lower due to dietary fibre, oxalate and phytic acid which inhibit the absorption of zinc. A substantial amount of copper is contained in beef and calf liver. Other foods rich in copper include sunflower seeds, nuts, avocado and shellfish. Plant sources of iron (non-haem iron) are wholegrain cereals and flours, leafy green vegetables, blackstrap molasses, pulses, such as, lentils and kidney beans, and some dried fruits while animal sources (of heam iron) include meat and marrow. Non-haem iron is less easily absorbed by the body than is haem iron. The amount of iron absorbed from various foods ranges from around 1 to $10 \%$ from plant foods and 10 to $20 \%$ from animal foods [16].Considering the limitations associated with the animal and plant sources of the trace elements, there is need to search for alternative sources of trace elements which are cheap, safe and readily available.

Mushrooms are neither plants nor animal. They are mostly heterotrophic saprobes feeding on generally, decaying plant and animal remains. They are naturally found in the wild but most mushrooms have not been domesticated [17]. Both the wild and the domesticated ones are safe source of both macro and micronutrients including important trace elements. This is due to their ability to degrade and accumulate substances from their growth substrates using their multilateral enzyme systems [18]. When domesticated, the nutrient status of the mushroom can be modified through amendment of the growth substrates with the requisite additives to achieve 
bioaccumulation of certain nutrients or elements of interest.This study presents trace elements bioaccumulation potentials of Pleurotus ostreatus cultivated on Banana leaves and Sawdust substrates and its implication in nutrition-based therapy.

\subsection{Collection of materials}

\section{Materials And Methods}

Crude oil used for this study was obtained from Agip Oil Company, Port Harcourt, Rivers State. Diesel was bought from NNPC mega filling station, Calabar, and spent engine oil was obtained from a mechanic workshop along Goldie Street, Calabar. Spawn of Pleurotus ostreatus was purchased from Royal Farms at Ikot Effanga Mkpa, Calabar, Cross River State. Rice bran was collected from a private owned rice mill in Ugep, Yakurr Local Government Area of Cross River State and Lime (gypsum) was bought from Watt Market in Calabar. Dry banana leaves and sawdust used for substrates composition were collected from the surroundings of the University of Calabar staff quarters and government owned timber market at MCC road, Calabar, respectively.

\subsection{Preparation of substrates}

Two substrate types were used for the cultivation of $P$. ostreatus. They were Banana leaves substrate (BL) and sawdust substrate (SD). These were standard substrates prepared using the methods adopted by $[5 ; 19 ; 20]$.

\subsection{Amendment of substrates with petroleum products}

Three types of petroleum products used were crude oil, diesel and spent engine oil. Each $1 \mathrm{~kg}$ of mushroom substrate received $0 \mathrm{ml}, 5 \mathrm{ml}, 10 \mathrm{ml}$ or $15 \mathrm{ml}$ of crude oil, diesel or spent oil. The amended substrates were separately packed into sterile mushroom bags (each measuring $30 \mathrm{x} 12 \mathrm{~cm}$ ) under aseptic conditions. Each of these bags was inoculated with Pleurotus ostreatus spawn. The open end of the bags were secured with a polyvinyl chloride (PVC) pipe measuring $3 \mathrm{~cm}$ long and $3 \mathrm{~cm}$ in diameter, wrapped with a rubber band and plugged with cotton wool [21]. The experimental units representing the control experiment $(0 \mathrm{ml})$ did not receive the oil treatments but were inoculated with the mushroom spawn as in the oil amended units.

\subsection{Spawn running}

The treated and the untreated (substrates in bags) experimental units were hung with ropes with ropes serially from the roof down with each line carrying a maximum of eight bags.

\subsection{Cropping}

Cropping began at the end of spawn running when spawning materials were completely colonized in the substrates with the fungal mycelial. The spawned bags were transferred to the cropping room and placed on wooden shelves. Cropping room was maintained at a temperature of about $25-30^{\circ} \mathrm{C}$, limited light was allowed and a relative humidity of $60-80 \%$ was maintained by sprinkling water on the floor and walls $[22,5]$. The floor of the cropping room was covered with sea sand soaked with water on a regular basis to maintain high level humidity. These bags were opened and lightly moisten with clean water twice a day using a simple spraying gun $[17,19]$, awaiting fruit-bodies formation and maturity.

\subsection{Analysis of heavy metals}

One gram (1 g) of each sample was carefully measured using an analytical balance and was ignited in a muffle furnace crucible dish before being poured into a digestion flask. $5 \mathrm{ml}$ of percloric acid was added to the ignited sample. This was followed by the addition of $15 \mathrm{ml}$ of Nitric acid before it was then digested in a Kjeidhal digestion apparatus. It was then allowed to cool and was dissolved and made up to $100 \mathrm{ml}$ before samples were taken in parts per meter ( $\mathrm{ppm}$ ) for analysis with atomic absorption spectroscopy at the wavelength of 360-730 $\mu \mathrm{m}$. The absorption was recorded for each element. Jenway atomic absorption spectroscopy 3603 model was used[23, 24].

\subsection{Data analysis}

Data were analyzed using SPSS version 21.0. Means were separated using Fisher's Least significant Difference (LSD) test.

\section{Results}

Table 1:Trace elements bio-accumulated in fruit-bodies of Pleurotus ostreatus cultivated on banana leaves and sawdust substrates.

\begin{tabular}{|l|l|l|l|l|l|l|l|l|l|l|}
\hline \multirow{2}{*}{ Oil treatments } & \multicolumn{10}{|c|}{ Test metals $(\mathrm{mg} / \mathrm{kg})$} \\
\cline { 2 - 14 } & $\mathrm{Cd}$ & $\mathrm{Cr}$ & $\mathrm{Co}$ & $\mathrm{Cu}$ & $\mathrm{Fe}$ & $\mathrm{Pb}$ & $\mathrm{Mn}$ & $\mathrm{Hg}$ & $\mathrm{Ni}$ & $\mathrm{Zn}$ \\
\hline Crude oil & 0.40 & 1.25 & 0.31 & 0.95 & 32.40 & 0.31 & 28.36 & 0.03 & 0.67 & 51.19 \\
\hline Diesel & 0.18 & 0.46 & 0.09 & 0.38 & 21.20 & 0.08 & 18.90 & 0.00 & 0.16 & 33.00 \\
\hline Spent oil & 0.28 & 0.95 & 0.16 & 0.52 & 14.93 & 0.13 & 13.92 & 0.01 & 0.35 & 27.22 \\
\hline
\end{tabular}

Values are means of three replicates $(\mathrm{P} \leq 0.05) . \mathrm{LSD}=0.02$ 
Table 2: Trace metals bio-accumulated in fruit bodies of Pleurotus ostreatus cultivated on banana and sawdustbased substrates treated to crude oil and some petroleum fractions.

\begin{tabular}{|l|l|l|l|l|l|}
\hline \multirow{2}{*}{ Oil treatments } & \multicolumn{5}{|c|}{ Trace metals (mg/kg) } \\
\cline { 2 - 6 } & Cadmium & Chromium & Lead & Mercury & Nickel \\
\hline Crude oil & 0.40 & 1.25 & 0.31 & *BDL & 0.67 \\
\hline Diesel & 0.18 & 0.46 & 0.08 & *BDL & 0.16 \\
\hline Spent oil & 0.28 & 0.95 & 0.13 & *BDL & 0.35 \\
\hline
\end{tabular}

Values are means of three replicates $(\mathrm{P} \leq 0.05) . \mathrm{LSD}=0.02 * \mathrm{BDL}=$ Below Detectable Level

Table 3: Reported literature values ( $\mathrm{mg} / 100 \mathrm{~g}$ dry weight basis) in mushroom

\begin{tabular}{|l|l|l|}
\hline Trace elements & Reported literature values & Reference \\
\hline Iron & $1.46-83.50$ & {$[25]$} \\
\hline Zinc & $2.98-15.80$ & {$[25]$} \\
\hline Copper & $7.10-9.50$ & {$[25]$} \\
\hline Manganese & $1.81-10.30$ & {$[25]$} \\
\hline Cadmium & $0.271-0.75$ & {$[25]$} \\
\hline Lead & $0.286-0.688$ & {$[25]$} \\
\hline Nickel & $0.118-0.514$ & {$[25]$} \\
\hline
\end{tabular}

Table 4: Recommended Daily Intake (RDI) of trace elements in literature

\begin{tabular}{|l|l|l|}
\hline Trace elements & Recommended Daily Intake (RDI) (mg/day) & Reference \\
\hline Iron & $28-30$ & {$[26]$} \\
\hline Zinc & 15.5 & {$[26]$} \\
\hline Copper & 2.2 & {$[26]$} \\
\hline Manganese & 5.5 & {$[26]$} \\
\hline
\end{tabular}

Table 5: Sources of trace elements and mushroom output required to meet RDI

\begin{tabular}{|c|l|l|l|l|}
\hline \multirow{2}{*}{ Oil treatments } & \multicolumn{4}{|l|}{ Mushroom $(\mathrm{g}) /$ Trace metals (mg/day) } \\
\cline { 2 - 5 } & Manganese & Copper & Iron & Zinc \\
\hline Crude oil & 30.00 & 230.00 & 95.59 & 30.28 \\
\hline Diesel & 29.41 & 560.00 & 141.50 & 46.97 \\
\hline Spent oil & 39.53 & 420.00 & 215.52 & 56.94 \\
\hline
\end{tabular}

\section{Discussion}

Assessment on the capacity of the test mushroom to bio-accumulate trace elements from petroleumrich substrates was assessed based on ten (10) elements, namely cadmium (Cd), chromium (Cr), cobalt (Co), copper $(\mathrm{Cu})$, iron $(\mathrm{Fe})$, lead $(\mathrm{Pb})$, manganese $(\mathrm{Mn})$, mercury $(\mathrm{Hg})$, nickel $(\mathrm{Ni})$ and zinc $(\mathrm{Zn})$ with special focus on copper, iron and zinc considering their application in health care delivery. At the end of the investigation the following observations were made.

The level of trace element content of mushroom is a function of the mushroom species and the chemical composition of substrate from which mushrooms take nutrients [27].Mallikarjunaet. al., (2013) recorded higher levels of trace elements in geochemically-burdened substrates and also documented the variability in amounts of trace elements bio-accumulated by four species of Lentinus [25]. They observed that Agaricus bitorquis best bio-accumulated the metals recording 32, 34, 0.38, 0.56, 2.0, 0.075 and 5. $\mu \mathrm{g} / \mathrm{g} / \mathrm{lof} \mathrm{cu}$, $\mathrm{Zn}$, As, Se, $\mathrm{Ag}, \mathrm{Cd}, \mathrm{Sb}$, and $\mathrm{Hg}$ respectively in geochemically-burdened substrates.They showed that mushrooms, in contrast to green vascular plants, significantly accumulated many elements including $\mathrm{Cu}, \mathrm{Zn}$, and $\mathrm{Cd}$ in their fruit-bodies. In the present study, observations made indicated similar activity with $P$. ostreatus. The ten metals analyzed for were found in reasonable levels except for mercury $(\mathrm{Hg})$ which was below detectable levels (BDL) in mushrooms harvested from the three test substrates. The highest amounts of trace elements were detected in crude oil-based substrates with zinc at the top of the list with $51.19 \mathrm{mg} / 100 \mathrm{~g}$. iron $(32.40 \mathrm{mg} / 100 \mathrm{~g})$ and manganese $(28.36 \mathrm{mg} / 100 \mathrm{~g})$ were next. Copper was not high in amount. Less than one milligram $(1 \mathrm{mg})$ of copper was bio-accumulated per $100 \mathrm{~g}$ of edible portion. In spent oil and diesel-amended substrates, zinc was still the highest bio-accumulated with values of $33.00 \mathrm{mg} / 100 \mathrm{~g}$ and $27.22 \mathrm{mg} / 100 \mathrm{~g}$ respectively. About $18.90 \mathrm{mg} / 100 \mathrm{~g}$ and $13.92 \mathrm{mg} / 100 \mathrm{~g}$ of manganese were extracted and retained in the mushroom fruit bodies harvested from diesel and spent oil rich substrates respectively. The amount of iron found in the test mushroom was, however, lower $(14.93 \mathrm{mg} / 100 \mathrm{~g})$ in fruit bodies harvested from spent oil when compared with those $(21.20 \mathrm{mg} / 100 \mathrm{~g})$ from diesel amended substrates while copper bio-accumulated more in fruit bodies obtained from spent oil than those from diesel-rich substrates. Generally, the presence of crude oil in the substrates seems to result in higher incremental levels of trace metals in the mushroom fruit bodies when compared with other additives. Spent oil ranked next in the amount of trace elements released into the mushroom growth substrates. Trace element content of spent oil has been documented [28]. Among the elements reported in spent oil is zinc $(\mathrm{Zn})$. The amounts of trace elements found in diesel-rich substrates were comparably low. Among these metals, zinc and iron were recorded in highest amounts. They asserted that 
mushrooms are good accumulators of zinc. Zinc was hitherto considered a threat to the environment and public health, but now, it is regarded as an important component of nutrition-based therapy in infant, maternal and community health interventions.

A comparison of the amounts of individual trace elements accumulated by mushrooms to that found in other food sources reveals that the highest amount of cobalt in plant-based foods is $0.050 \mathrm{mg} / 100 \mathrm{~g}$ (in chocolates) and $0.04 \mathrm{mg} / \mathrm{kg}$ (in dried fruits and nuts); in animal products, the highest cobalt value (0.046 $\mathrm{mg} / 100 \mathrm{~g}$ ) is recorded in crustaceans and mollusks. In ready meals, soups and breakfast cereals, the highest amount is $0.08 \mathrm{mg} / \mathrm{kg}$. The food with the lowest cobalt value is milk $(0.001 \mathrm{mg} / 100 \mathrm{~g})$. From the present study, cobalt range of 0.09 to $0.31 \mathrm{mg} / 100 \mathrm{~g}$ was recorded in mushroom fruit bodies analyzed. The values of copper in mushrooms assessed in this study ranged from 0.38 to $0.95 \mathrm{mg} / 100 \mathrm{~g}$ but in common fruits like orange, pawpaw, pineapple and avocado, the range are 0.06 in orange to a maximum of $0.28 \mathrm{mg} / 100 \mathrm{~g}$ in avocado. In vegetables like onions and egg plants, cobalt levels of 0.06 to $0.14 \mathrm{mg} / 100 \mathrm{~g}$ are reported. Iron content of foods ranges between $1.46 \mathrm{mg} / 100 \mathrm{~g}$ to $83.5 \mathrm{mg} / 100 \mathrm{~g}$. The mushroom species in this study, bio-accumulated up to 32.40 $\mathrm{mg} / 100 \mathrm{~g}$ of iron. Zinc was the highest bio-accumulated of the trace metals assessed with levels ranging from $27.22 \mathrm{mg} / 100 \mathrm{gto} 51.19 \mathrm{mg} / 100 \mathrm{~g}$ (Table 1) as compared to the range of 5.10 to $84-40 \mathrm{mg} / 100 \mathrm{~g}$ in common foods like cheese and raw oyster respectively [24] (Mallikarjunaet. al., 2013).

Most of the values reported for common trace elements per $100 \mathrm{~g}$ of the edible portion of $P$. ostreatus in this study are within the range reported in literature (Mallikarjuna et. al., 2013, Coffman, 1996). However, values recorded for copper in this study were slightly lower and those for manganese and zinc are above. For levels of manganese and zinc, it is advantageous as a little quantity of mushroom is enough to meet the Required Daily Intake (RDI) for the elements. A critical study of the RDI vis-à-vis the values obtained for the elements shows that the trace element levels are adequate when reference is made to the RDI presented in Table 4. A more practical approach is to estimate the amount of mushroom in grams necessary to supply the requisite level of trace element to meet the RDI. The value estimates are presented in Table 5. The estimation shows that daily consumption of about $20-39.5 \mathrm{~g}$ of mushroom (dry wt.) is adequate to supply the RDI for manganese and about $30.28-56.94 \mathrm{~g}$ of $P$. ostreatus consumed is adequate to meet the body needs for zinc daily.

Comparing the above estimates in mushrooms with the amounts of plant-based foods required to meet the RDI for the various trace elements, it is clear that normal amount of food we consume is quite inadequate to provide the requisite levels of the necessary trace elements at any point in time. Consumption of excessive quantity of a particular food in an attempt to build up the levels of trace elements in the body is equally disadvantageous as it may result in over-feeding and possibly, constipation and flatulence. To depend on food supplements so as to meet the RDI for the various trace elements is an expensive plan. In addition, some of the supplements are synthetic, non-biodegradable and even when they degradable, the possibility of leaving behind within the system, dangerous residues, is imminent. Domestication of mushrooms has made safe mushrooms readily available all year round at reasonably low rates.

\section{Conclusion}

The production of trace elements-fortified mushrooms is an innovation aimed at providing these important nutrient elements in a form compatible with the system and in good supply at all times at an affordable price to patients with nutrients deficiency syndrome. This will serve as a veritable nutrition-based intervention to restore health to teaming population of people suffering from nutrient-related ailments without necessarily reaching for synthetic nutraceuticals.

\section{References}

[1]. Nkang, A. E., Eko, M. E. and Markson, A. A. Biology: Lower Plant Forms. Calabar, Nigeria. Galax-Star Printers and Publishers, 2005.

[2]. Ogbo, E. M. and Okhuoya, J. A. Bioremediation of aliphatic, aromatic, resinic and asphaltic fractions of crude oil contaminated soils by Pleurotus tuber-regium (Fr) Singer- a white rot fungus. African Journal of Biotechnology, 7(23),2008, 4291-4297.

[3]. Adenipekun, C.O. and Fasidi, I.O. Degradation of selected agricultural wastes by Pleurotus tuber-regium (Fries) Singer and Lentinus subnudus (Berk) - Nigerian Edible Mushrooms. Advances in Food Sciences 27 (2), 2005, 61 - 64.

[4]. Isikhuemhen, O. S., Anoliefo, G. O. \&Oghale, O.I. Bioremediation of crude oil polluted soil by the white rot fungus Pleurotus tuber- regium (Fr.) Singer. Environmental Science Pollution Research International, 10(2), 2003, 108-112.

[5]. Markson, A. A., Madunagu, B. and Bassey, G. Assessment of growth support potentials of different substrates for the cultivation of Volvariellavolvacea. Journal of Biology, Agriculture and Healthcare, 2(3), 2012a, 52-58.

[6]. Adenipekun, C. O. Bioremediation of engine oil-polluted soil by Pleurotus tuber-regium Singer - a Nigerian white rot fungus. African Journal of Biotechnology.7 (1).2004, 055-058.

[7]. Adenipekun, C.O., Olanrewaju, O.O. and Ogunjobi, A.A..Bioaccumulation of heavy metals and nutrient contents by two white rot fungi in crude oil polluted soils. Researcher 3 (5), 2011, $13-20$.

[8]. Markson, A. A., Bassey, G. A., Agba, M. O., Akpan, J. B. Myco-remediation efficacy and bioaccumulation potential of Pleurotus ostreatus cultivated on petroleum product-amended substrates (unpublished), 2015.

[9]. Black, M. M. Zinc deficiency and Child development. American Journal of Clinical Nutrition, 68(2), 1998 464S-469S.

[10]. Holden S., Hudson, K., Tilman J. and Wolf D.. The Ultimate Guide to Health from Nature, Asrolog publication, 2003.

[11]. http://healthcare.utah.edu/healthlibrary/related/doc.php?type=19\&id=cobalt. Cobalt.Retrieved March 27, 2017. 
[12]. Rahrig, P. What role does Zinc play in human health? https://www.galvanizeit.org/knowledgebase/article/what-role-does-zinc-playin-human-health. Retrieved March 37, 2017.

[13]. United Nations Children Fund (UNICEF). Improving Child nutrition: the achievable imperative for global progress.United Nations PlazaNew York, NY 10017, USA. Email: pubdoc@unicef.org .www.unicef.org http://www.unicef.org.2013 Pp. 124.

[14]. World Health Organization.Trace Elements in Human Nutrition.India, Macmillan Publishers, 1996.Pp. 160.

[15]. Kaufman, C. Foods to fight Iron Deficiency http://www.eatright.org/resource/health/wellness/preventing-illness/iron-deficiency. Retrieved March, 27, 2017.

[16]. Whitbread, D. and House, P. Top ten foods highest in iron. https://www.healthaliciousness.com/articles/food-sources-ofiron.php.2016. Retrieved March, 272017.

[17]. Oei, P. Mushroom cultivation: appropriate technology for mushroom growers. Leiden, The Netherlands. Backhuys publishing. 2003.

[18]. Reddy, C. A. The potential for white rot fungi in the treatment of pollutants.Current Opinion Biotechnology, 6, 1995, 320- 328.

[19]. Markson, A. A., Madunagu, B. E., Enyiko, E. D.Growth Performance of Pleurotus ostreatus (Jacq. Et. Fr.) Kummer on different substrates treated with used automobile engine oil.International Journal of Recent Scientific Research 3(5), $2012 \mathrm{~b}, 384$-388.

[20]. Markson, A. A., Madunagu, B. E., Akpan, U. D., Eshiet, E. I. Growth Influence of Some Additives on the Mycelial Growth and Fruit Body Development of Pleurotus ostreatus (Jacq. Et. Fr.) Kummer, Journal of Biology, Agriculture and Healthcare, 2 (3),2012c, 59-68.

[21]. Bassey, G. A. Growth performance of Pleurotus ostreatus (Jacq. ex fr.) P. Kumm on petroleum amended mushroom substrates. Master Thesis. Department of Botany.University of Calabar, Calabar. Nigeria. 2014, Pp. 120.

[22]. Fasidi, I. O. Substrate sourcing and preparation for mushroom cultivation. Training workshop on cultivation of tropical mushrooms 20th -22nd November, 2006 at University of Ibadan, Oyo State.

[23]. Crosby, W. T. Determination of metals in foods. A review.The Analyst, 102,1977, 223-268.

[24]. Onwuka, G. I. Food analysis and instrumentation. Theory and Practice. Lagos. Nigeria.Nahthali Print.2005, Pp. 219.

[25]. Mallikarjuna, S. E., Ranjini, A., Devendra J., Haware, M. R., Vijayalakshmi, M. N. Shashirekha, and Rajarathnam, S. Mineral Composition of Four Edible Mushrooms. JournalofChemistry.2013, http://dx.doi.org/10.1155/2013/805284.

[26]. Indian Council of Medical Research (ICMR).Nutrient Requirements and Recommended Dietary Allowances for Indians, A Report of the Expert Group of the Indian Council of Medical Research, NationalInstitute of Nutrition, Hyderabad.

[27]. $\quad$ Randa Z,.andKučera J. Trace elements in higher fungi (mushrooms) determined by activation analysis. Journal Radioanal Nuclear Chemistry 259, 2004, 99-107.

[28]. Dominguez-Rosado, E. and Pichtel, J. Chemical characterization of fresh, used and weathered motor oil via GC/MS, NMR and FTIR techniques. Proceedings of the Indiana Academy of Science. 112(2),2003, 109-116. 